\title{
JE SCHUMPETEROVA VIZE KONCE KAPITALISMU STÁLE RELEVANTNÍ?
}

Václav Klaus, Praha*

Josef Alois Schumpeter byl velkým ekonomem. Od první chvíle jsem ho obdivoval a hodně jsem se toho od něj naučil. Většina lidí neví, že se tento velký ekonom narodil v roce 1883 na území dnešní České republiky, v jihomoravské Třešti, která byla v té době součástí Rakousko-uherské monarchie. Patřil do velmi významné skupiny „rakouských Moravanů“, která zahrnovala takové velikány, jakými byli Sigmund Freud, Gustav Mahler, Karl Kautsky, Ernst Mach, Robert Musil a mnoho dalších. „Rakouským“ ekonomem se stal po ukončení univerzitních studí ve Vídni, ,americkým“ ekonomem $\mathrm{v}$ třicátých letech po útěku $\mathrm{z}$ Evropy před Hitlerem. Byl pravděpodobně jediným ekonomem, který mohl v první polovině dvacátého století v mezinárodní proslulosti soutěžit s Keynesem.

Díváme-li se pozorně na jeho pojetí ekonomie a na jeho ekonomickou metodologii, je třeba říci, že nebyl ortodoxním exponentem rakouské ekonomické školy (a já bych dodal, že ani být nemohl - na Harvardu ve třicátých a čtyřicátých letech to nešlo. Gottfried von Haberler byl naprostou výjimkou). Fritz Machlup, další významný Rakušan, který v té době žil v USA, kdesi řekl, že u Schumpetera převládá ,metodologická tolerance nebo metodologický pluralismus“, což považuji za výstižný výrok. (Dodal bych, že si to může dovolit jen skutečný velikán.)

Když jsem na konci padesátých let, stále ještě v tuhém komunismu, začínal své formální ekonomické vzdělávání, se jménem Schumpeter jsem se na pražské VŠE nesetkal. Objevil jsem ho až v polovině šedesátých let při své aspirantuře, kdy jsem byl na zkoušku z dějin ekonomických doktrín nucen věnovat několik týdnů studiu jeho úžasného díla History of Economic Analysis. ${ }^{1} \mathrm{~V}$ té době to u nás paradoxně bylo možné, komunistický režim byl v mnoha ohledech již relativně „měkký“ a určitě nefungoval nijak důsledně.

Při svých vysokoškolských studiích jsem měl př́ležitost setkávat se pouze s marxistickou politickou ekonomií, takže mít najednou v jedné ruce tuto Schumpeterovu knihu a v druhé šesté vydání Samuelsonovy učebnice ${ }^{2}$ bylo úplným zjevením. Vím, že tímto tvrzením bývají američtí klasičtí liberálové (a libertariáni) poněkud zmateni, ale já mu-

* Přestože Josef Alois Schumpeter je jedním z nejvýznamnějších ekonomů prvé poloviny dvacátého století, povědomí o jeho díle je v Čechách - zejména mezi nejmladší ekonomickou generací značně kusé. Proto redakci zaujal projev Václava Klause, který přednesl ve Washingtonu 28. 5. 2008 (kdy mu byla udělena cena Juliana Simona v Competitive Enterprise Institute). Domníváme se, že pro čtenáře Politické ekonomie by mohl být český překlad hlavních myšlenek Klausovy přednášky zajímavý.

1 Schumpeter, J. A.: History of Economic Analysis. New York, Oxford University Press, 1968.

2 Samuelson, P. A.: Economics (6th edition). McGraw-Hill, New York, 1964. 
sím trvat na tom, že bez knih tohoto typu bych nebyl schopen následně dostatečně ocenit Miltona Friedmana a celé Chicago, Misese a Hayeka, Buchanana a Tullocka. Schumpeterova kniha mi pomohla pochopit skutečnou podstatu ekonomie a obrovský rozsah záběru ekonomické analýzy. Schumpeterovy znalosti se mi zdály být neuvěřitelně široké a hluboké, pro normálního člověka nepředstavitelné a nedosažitelné. Čili, z mé strany, opravdová pokora.

V té době, to je před více než čtyřiceti lety, jsem pracoval v Ekonomickém ústavu Československé akademie věd. Snažili jsme se pochopit, vysvětlovat sobě i navenek a hlavně popularizovat nemarxistické ekonomické teorie (tehdy si dovolit říkat, že to byly „nemarxistické“, nikoli „buržoazní“ ekonomické teorie, bylo průkopnické). Mezi těmi myšlenkami, které nás tehdy oslovily, byl i Schumpeterův koncept inovací, podnikatelství a „tvořivé destrukce“. Ten byl prvně zformulován už v roce 1912, v německé verzi daleko později anglicky publikované knihy Theory of Economic Development. ${ }^{3}$ Podle Schumpetera právě inovace, podnikatelství a tvořivá destrukce představují skutečnou bázi kapitalismu a ekonomického rozvoje vůbec.

Když jsem později četl jeho knihu Capitalism, Socialism and Democracy, ${ }^{4}$ která byla publikována v Anglii na počátku čtyřicátých let - spolu s Hayekovou The Road to Serfdom a Orwellovou Devatenáct set osmdesát čtyři ${ }^{5}$ - setkal jsem se s trochu jinou teorií, s jeho evoluční teorií konce kapitalismu, způsobeném úspěšností jeho fungování. (Ted' mi opravdu nejde o v literatuře probíhající spor o souladu či rozporu mladého a „starého“ Schumpetera.) Jeho hlavním argumentem bylo - a tak mi to utkvělo v paměti - že se inovace stanou rutinní záležitostí, že bude pokrok „zmechanizován“, že problémy budou ,,̌rešeny“ pomocí rozumu a vědy, že bude podnikatelství nahrazeno čirou „kalkulací“, že se bude vytrácet individuální motivace, že začne převládat kolektivistická mentalita, a že ve velkých koncepcích začne dominovat týmová práce, která individualitu podnikatele odsune zcela do pozadí. A tím kapitalismus skončí. Schumpeter to nevítal, ale nemyslel si, že to bude konec světa, historie, pokroku a rozvoje. Jeho pohled nebyl hayekiánský, ani orwellovský - jejich postoje jsou mně daleko bližší.

Tehdy pro nás měla Schumpeterova teorie zvláštní význam. Žili jsme ve světě, kde byla oficiální doktrínou socialistická revoluce a centrální plánování, nikoli spontánní evoluce a soukromá iniciativa. Očekávalo se, že kapitalismus skončí díky svému neúspěchu a stále hlubší krizi. Dnes už se to př́liš odvážné nezdá, ale tvrdit v komunistické zemi, že kapitalismus eventuálně skončí díky svému úspěchu (nikoli neúspěchu), bylo velmi revoluční. Říkat to dostatečně nahlas bylo v naší zemi možné jen v relativně slibné atmosfére druhé poloviny šedesátých let, v éře, která kulminovala Pražským jarem roku 1968 a která byla velmi rázně ukončena sovětskou invazí a okupací.

Schumpeterovu teorii konce kapitalismu jsme používali jako argument v diskuzích se stoupenci marxistické politické ekonomie a komunistické ideologie. Pro tento účel

Schumpeter, J. A.: Theory of Economic Development. Harvard University Press, Cambridge, Mass. 1934

4 Schumpeter, J. A.: Capitalism, Socialism, and Democracy. Harper and Brother, New York 1942

5 Hayek, F. A.: The Road to Serfdom. Routledge, London and Chicago 1944; Orwell, G.: 1984. Naše vojsko, Praha 1991. 
jsme neměli žádné velké ambice pouštět se do její kritiky, ale i tehdy jsme měli různé pochybnosti.

Jak se na to dívám dnes? Na první pohled je zřejmé, že je tato teorie př́liš pesimistická. Čili, jejím prvním problémem je to, zda odpovídá realitě, zda svět poslouchal a následoval Schumpeterovy predikce. Sice zatím nemáme několik století empirické evidence, ale od momentu, kdy Schumpeter zformuloval tyto své futurologické předpovědi, uplynulo již více než šest desetiletí. Kapitalismus, tj. tržní ekonomika založená na soukromém vlastnictví, nejenom existuje, ale rozvíjí se v daleko větším počtu zemí světa než kdykoli jindy v minulosti a proces „tvořivé destrukce“ a nekonečný proud inovací jsou silnější než kdykoli dř́ve.

Samožrejmě známe různá vážná omezení fungování kapitalismu, ale ty obavy, které byly vysloveny ve třicátých a čtyřicátých letech, tedy v éře Schumpeterova pobytu v Americe - velký byznys, monopolistická nebo nedokonalá konkurence, oddělení vlastnictví od řízení, oslabování přirozeného ducha (animal spirit), demotivace spojená s bohatnutím společnosti, kolektivně organizovaný inovační proces - se nepřekonatelnou bariérou dalšího fungování kapitalismu nestaly.

Důležitějšími se ukázaly být jiné věci: stále expandující paternalismus „státu blahobytu“, rostoucí aspirace státu regulovat společnost ve snaze vyhnout se všem selháním trhu (reálným nebo domnělým), vymáhání „standardů“, které zvyšují náklady a v podstatě některé ekonomické aktivity zcela likvidují, ,zelená“ ideologie, a její v současnosti nejagresivnější varianta - alarmismus globálního oteplování. Tyto věci a v této podobě Schumpeter nepředvídal.

Je nutné zmínit ještě jednu věc. Jako někdo, kdo se podílel na odstraňování komunismu a budování svobodné společnosti, musím připomínat další důležitý argument proti platnosti Schumpeterovy teorie - kolaps komunismu a explicitní přijetí kapitalismu téměř na celém světě. To také není v souladu s původní Schumpeterovou hypotézou.

Druhou věcí je pohled ekonomické teorie. Mám pocit, že je třeba vznášet vážné otázky. Je celá myšlenka inovací teorií? Není jenom pouhým popisem známého a snadno pozorovatelného jevu, který by měl být nějakou teorií vysvětlen? Zaslouží si být tato teze považována za vysvětlení tak komplikovaného a mnohadimenzionálního procesu, jakým je dynamika kapitalismu?

Vždy jsem měl problém vysvětlovat tuto Schumpeterovu teorii studentům. Neekonomům se obvykle líbila, ekonomům nikoli. Považovali ji za prázdnou a povrchní. A netestovatelnou.

Vím, že je to odvážné tvrzení. Zejména od člověka, který vždycky tvrdil, že Schumpeter rozuměl ekonomické vědě více než kdokoli jiný. Ve svém „Kapitalismu, socialismu a demokracii“"se však od ekonomie posunul př́liš daleko a tím se zřekl i její mocné a lidskou mysl k disciplíně přivádějící metodologie. Jsem přesvědčen o tom, že je to chyba - jeho i všech, kteří se dopustí stejné, jak se ted’ říká, interdisciplinární chyby.

Dnes bychom měli věnovat pozornost dalším faktorům a procesům, které mohou přivést kapitalismus ke konci. Patří mezi ně tradiční, ale v dnešním světě postdemokracie nesmírně expandující nedůvěra v schopnost člověka a v nezastupitelné přínosy trhu. Samozřejmě to není žádnou novinkou, protože radikální útoky vůči trhu existovaly vždy, ale já dnes vidím rozdíl. V minulosti byl trh napadán převážně socialistickými ar- 
gumenty a heslem o „zbídačování mas“. Nyní se toto heslo změnilo v něco daleko nebezpečnějšího - mluví se o zbídačování (či destrukci) planety Země.

Je v tom mnoho podobností, ale jedna věc je jiná. Důkazy, že se životní úroveň lidí zvyšuje, je možné získat v relativně krátké době. Abych obrátil slavnou Keynesovu formulaci, je to možné dříve, než budeme všichni mrtvi. Nyní bude nutné čekat celá staletí, než získáme přesvědčivý důkaz, že naše planeta není zničena nebo že nestojí před zničením.

Černé pasažérství s touto novou myšlenkou je daleko snazší. Ambiciózní politici, kteří se snaží rídit svět a své spoluobčany, desetiletí snili o tom nalézt tak líbivou a od reality tak „imunizovanou“ doktrínu. Léta či desetiletí chladného počasí ji nevyvrátí. Stala se novým náboženstvím. Protože si jsem jist, že se tato ideologie stala hlavním prostředkem $\mathrm{k}$ destrukci svobodného trhu, napsal jsem knihu o globálním oteplování, resp. o zneužití myšlenky globálního oteplování. ${ }^{6}$

Schumpeter se, doufejme, ve svých predikcích mýlil. A navíc je už téměř šest desetiletí mrtev.

6 Klaus, V.: Modrá, nikoli zelená planeta, nakl. Dokořán, Praha 2007 